\title{
The Consciousness of Death and the Extreme Loyalty An Exploration of Hagakure from the Perspective of Body
}

\author{
$\mathrm{Han} \mathrm{Xu}$
}

\author{
Hongyi Honor College of Wuhan University, Wuhan University, Wuhan, Hubei 430072, China \\ 2019301120044@whu.edu.cn
}

\begin{abstract}
The Edo Period was a peaceful period of the buke politics, and the word "Bushido" began to appear. Hagakure, written by Yamamoto Nagasu, is one of the most important classics of Bushido at that time. Hagakure was less influential than other Bushido books in the Edo period, and was ever banned in the Saga vassal state for a time. During the Second World War, however, Japanese nationalists made it a required reading for all, and postwar Japanese right-wingers praised parts of the book highly. The status change of Hagakure from non-center to center seems to indicate that it has some particularity. Therefore, this paper will investigate the Bushido thought related to "the consciousness of death" and "the extreme loyalty" in Hagakure from the perspective of body and try to provide answers to the above questions.
\end{abstract}

Keywords: The Edo Period, Hagakure, body, The consciousness of death, the extreme loyalty

\section{INTRODUCTION}

The Edo Period refers to the period of two and a half centuries from 1603 when Tokugawa ieyasu established the shogunate in Edo (now Tokyo) to 1868 when the Meiji government was established. The Edo period was a peaceful period of the buke politics. The samurai began to turn into politicians or administrative bureaucrats, the the word "Bushido" began to appear. The bushido of the Edo Period was deeply influenced by Chinese Confucianism. Some scholars believe that if the bushido theory of the Edo Period abandoned Confucianism, the bushido system could not be established.

Until now, academic circles have investigated and researched bushido in Edo Period from many angles. However, with the rise of new academic schools such as postmodernism, the whole boundary of traditional literature, history and philosophy has been broken through, and the fields that have been neglected for a long time in traditional studies have been explored, among which body history is one of the significant new perspectives. There are a lot of descriptions and expressions related to the body in the Bushido classics of the Edo period, especially in Hagakure.

Mishima Yukio thinks Hagakure is a philosophical work on bushido. The philosophy of Hagakure contains three aspects, which are: the philosophy of action, the philosophy of life toward death and the philosophy of love.

Hagakure was written by a Saga vassal state samurai called Yamamoto Nagasu and Tashiro. They worked together and completed it in 1716, when the Feudal system in Japan had entered a period of stability. The book consists of eleven volumes. Chapter one and chapter two focus on the mind of samurai; chapter three, four, five, and six are mainly about family and history of the Island; chapter seven, eight, and nine introduce the words and deeds of the samurai of Kao Island. Hagakure was written in the style of quotations. The process and form of the book were similar to the Analects of Confucius. It mainly included the remarks of Yamamoto Nagasu and also recorded the words and deeds of others, so it is also called The Analects of Yamamoto Nagasu. The main purpose of Hagakure is to philosophically confirm the professionalism of the samurai. The book begins with a clear message: "Death is the name of the warrior. [1] "

Hagakure was much less influence than other samurai classics in the Edo period, and was ever banned in the Saga vassal state for a time. During the Second 
World War, however, Japanese nationalists made it a required reading for all, and postwar Japanese right-wingers praised parts of the book highly. This seems to indicate that there is something special about the bushido thought in Hagakure that can touch the heart of the Japanese people. Therefore, this paper will take Hagakure as the center, from the perspective of body view, to explore the bushido thought related to "the consciousness of death" and "the extreme loyalty" in Hagakure and then examine the particularity of Hagakure [2].

\section{THE BUSHIDO THOUGHT IN HAGAKURE}

Yamamoto Nagasu (1659-1719), the narrator of Hagakure, was born into a samurai family in Saka vassal state. His father's name was Yamamoto Shigengcheng. Yamamoto was weak since the young age, "insufficient water vapor", noisy but very sensitive. He had two teachers, Ishida Icheding, a Confucian in Saka, and Monk Chamran, who retired and lived in Matsurose. Ishida Icheding believed that "do not be timid, do not cut off the family name, useful to the Lord" are the three principles that the warrior must fulfill. Monk Chamran believed that there are four most important things in life: bushido, loyalty to the Lord, filial piety to parents and compassion. Yamamoto was deeply influenced by the two teachers and remained loyal to his master until his death. He even wanted to "die" for his master, but the shogunate banned him from doing so. Eventually, Yamamoto went home to practice Buddhism and lived in seclusion in a kusanam on the outskirts of Saga city. During his seclusion, He often talked about his outlook on life with Tashiro. Tashiro recorded all these conversations and compiled them into a book called Hagakure

The core parts of Hagakure are the first and second volumes. According to Mishima Yukio, Hagakure is not a cynical counterargument, but the wisdom of action and the survival of the decision of the natural and adverse delivery of the world [2]. Hagakure is full of direct and indirect expressions of dissatisfaction with the contemporary society. For example, "Nowadays, people think they are intelligent and have discrimination in thought. They do not pursue superior combat skills. I hope the young people can reflect on themselves.[2]". Some scholars pointed out that Hagakure inherited the traditional bushido thought of advocating killing and dedicating himself unreservedly to the Lord in the early days, and also represented the idea of the samurai who still remembered the killing style of the Warring States in the peacetime, which seemed quite out of time. It can be seen that bushido thought in Hagakure was not the mainstream at that time, it was more a critical attitude to the Edo Period society and many new changes in the samurai class, and then pointed out that it is the right approach. Therefore, this paper holds that before discussing the bushido thought in Hagakure, it is necessary to give a brief description of the background of the Edo Period and the appearance and condition of the samurai class in that period.

The long peace of the Edo Period promoted agriculture and commerce. Land was the main source of tax revenue for the Tokugawa shogunate, and Edo became the political, economic, and cultural center of the country. In order to maintain the tax base and social order, the Shoyoshi era began to freeze social classes, prohibiting samurai from leaving their masters, prohibiting peasants from giving up their land to become citizens, and prohibiting citizens from owning land. After 1600, the Tokugawa Shogunate continued these policies, with samurai, peasants, and townspeople all tending to intermarry within their respective classes, thus reinforcing each class's own cultural style. In culture, the development of business led to rise of the new citizen culture, for instance, the Saikaku Ihara's (1642 -- 1693) haikai, Chikamatsu Monzaemon's (1653 -- 1724) script and Kitagawa Utamaro's (1753 -- 1806) the beauty of the picture. At the same time, the aristocratic culture of the upper reaches of the buke family continued to flourish: Noh plays continued to be performed, poetry was written in Chinese, and the Kano school and other artists continued the tradition of medieval ink painting [3].

Yamamoto, however, thought that behind the facade of prosperity lurked a worry. Mishima Yukio noted Yamamoto's concerns. "Men's fashion, it seems to be much more elaborate than women's fashion, and I don't think it's just modern Japan... During the Period of Yuan $\mathrm{Lu}$, the focus on luxury and beauty was not only shown in the clothing, but also in the style of the swords carried by the warriors, the hilt and scabbard of the swords were full of style and craftsmanship. Colorful fashion, bewitched the people of that time" ; "In addition, the feminization of men in modern Japanese society is constantly being discussed......But the problem of masculinity is not new. The rugged masculinity of the Warring States period had disappeared, and after the stability of the Tokugawa Shogunate regime, the feminization of Japanese men immediately appeared [2]. Moreover, in Yamamoto's view, many of the warriors of the Edo Period were either Mired in material desires or engaged in seeking employment with specific skills. Yamamoto believed that all these phenomena existed in the samurai class in the Edo Period needed to be corrected. Accordingly, he put forward the unique bushido thought in Hagakure, which not only attacked the "current evils", but also carried on the past and opened the future. This thought will be discussed in detail below.

The core of Hagakure is death, which is the action philosophy of "the consciousness of death". It points out 
how the samurai should act in life and what the end result of their life should be, as well as the ultimate life problems the samurai face. Hagakure emphasizes that the samurai, faced with life and death decisions, had to die decisively, without regret, without hesitation, even if the dog died, because in Yamamoto's view, the rationalist thinking about life and death is an excuse for cowards to live [4] . Hagakure begins by saying, "The bushido is to see through death. In the dilemma of life and death, to make a decisive decision, first choose to die ", "death is the purpose, this is the most important bushido [1]."

In the general treatises of Hagakure, Yamamoto put forward the four duties, or the four "vows", that is, in the practice of bushido must not lag behind others; There should be for the Lord; Filial piety; Taking compassion as the basic spiritual tone throughout the book, the author further puts forward the concrete ways to realize the four vows: first, the warrior is the way to death; second, the absolute loyalty to the Lord [5]. In addition, this paper holds that the way of death of warriors in The Book contains the requirement of absolute loyalty to the Lord.

In the samurai's path to death, Hagakure highly relates the "consciousness of death" with the samurai's reputation. According to Shuo Wen, a Chinese Classics, "reputation" contains two meanings: "name" -- "inside" -- one's own identification and consciousness of its inner value, and "reputation" -- "outside" -- the society's identification of its value. This explanation is still used in Japanese dictionaries, and the explanations of each dictionary are similar in terms of "self excellence" and "good evaluation [6]." Fame is more important than life is an important part of samurai morality. In the opinion of Chang Chao, if you do not choose to die, even if you live, you will be ridiculed as a coward [5]. It puts his family and posterity to eternal shame, and either keeps him from ever developing a high sense of self-identity, or leaves him to sink to the ground without any sense of shame. "Diligent in the service and bushido, ready to die in battle, the spiritual consciousness of the thorough to the decisive achievement of death, there will be no shame. If you don't pay attention to this aspect, you will live in desire and capricious. Don't be ashamed to shrink from things. [1]" Mishima interprets, often toward the choice of life and death just want to elaborate a kind of wisdom, that is, no matter what the situation, people of the self life of the active end, at least in the final limit can remain human dignity [2].

As for the absolute loyalty to the Lord, Hagakure says, "Compared with the achievements of a warrior, the best thing to do is to die for the Lord [2]." In the eyes of Yamamoto, the ultimate goal of serving the Lord is "the consciousness of death." But how to face death, Hagakure says:"Bushido is the mania for death, that is, the 'mania for death' itself...... Bushido is action, action is still in the use of discrimination, will lag behind people, action does not need to consider the two words of loyalty and filial piety, in bushido, only 'crazy death', naturally contains loyalty and filial piety [1] ". Ignoring the "reason" and "way" advocated by Confucianism at that time, Yamamoto often advocated "crazy" in thought and action, and replaced rational thinking and judgment of right and wrong with "crazy". [5]

In a word, in terms of the bushido thought in Hagakure, "That is, sacrifice oneself to the Lord at the cost of one's life and family, and first of all, one must cultivate oneself with the three virtues of wisdom, benevolence and bravery before doing anything [1]". "Consciousness of death" is the ultimate aim of absolute devotion to public service, and absolute devotion to public service is the core requirement of "consciousness of death". The combination of the two forms forms the radical bushido thought in Hagakure, which emphasizes body and action and takes death as the core concept.

\section{SAMURAI'S APPEARANCE, WORDS AND DEEDS -- REGULAR EXPRESSIONS OF BODY LANGUAGE}

As discussed above, Hagakure is a philosophy of action about the warrior's "consciousness of death" and absolute devotion to public service. There are many expressions about the body shape of the samurai and how the samurai should act in Hagakure, which may form a side of the body view of the Bushido in the Edo Period.

In terms of appearance, Hagakure stresses that the samurai should dress with care. "Samurai in the 1950s and 1960s had to bathe every morning, set their hair, and put perfume on their hair. Manicure hands and feet nails will be polished with volcanic stone, painted with gold grass and so on, and will not be idle in dressing up their own...... Whether you die today or tomorrow, no matter when you die, you should have a good attitude of determination to die. If you die in a messy and ugly battle, your level of consciousness is questionable and your enemies will despise you [1]." It can be seen that Yamamoto believed that the reason why a warrior should pay attention to grooming was so that he could die gracefully and calmly at any time, so as to preserve the honor and dignity of the warrior. Going to death with neat appearance is a reflection of the consciousness of samurai at ordinary times. This view may be related to the unique Japanese view of filth, but due to the lack of relevant information, this paper does not discuss more, but only to raise questions.

"To cultivate an exceptional temperament, always look in the mirror and correct yourself...... Face is the foundation of service. Those who show their ability in the face are not taken seriously; To assume a calm, but not severe, pose, form, and expression is less 
natural; Preferably a truly modest person with a dark, chiseled, masculine face and a quiet demeanor [1]." In this passage, Hagakure states that a masculine face is a better face for public service. Nitobe Inaz in his book Bushido, points out that the most manly warrior was originally produced in the long term and the adventurous spirit of a group of people, in the continuous elimination, out of cowardice, only those Emerson's "all male, like beasts rough powerful race" to survive, "shi" family and class [7]. In the initial stage of the development of the samurai, the main responsibility of the samurai was to serve the people with martial arts skills and protect the nobles and their family manor. The samurai class valued the martial art rather than the wendao. However, after entering the Edo period, bushido began to emphasize the aspect of "literature" due to the long period of peace, the development of industry and commerce, the prosperity of civic culture, and the spread of Confucianism. The tadashi theory, the representative figure of Yamanasu's behavior, became the mainstream, and the image of samurai gradually tended to be gentle and elegant. Hagakure, which represents the old bushido theory, criticizes the social phenomenon and emphasizes that the face of the warrior who truly serves his duty should have distinct male beauty.

It can be seen from the above two paragraphs that the discussion of samurai appearance in Hagakure is still focused on the realization of the two ways of bushido: "consciousness of death" and absolute devotion, and the samurai's appearance and body form are only the expressions and forms of better realization of these two ways.

However, in Hagakure there are also some unique appearance expression worthy of attention, such as "Tang Red - rouge powder, it is good to often put into the arms, in case of something, such as after waking up or in the morning, when the face is ugly, some rouge powder is good [1]". Behind this suggestion to the samurai to improve their appearance, in fact, it reflects Yamamoto's apparent rejection of the samurai's inner feelings, which may be summed up as Yamamoto unconsciously proposed the discipline that the samurai should deny themselves. Nitobe Inaz has expressed some views on the self-denial of samurai and even the Japanese. He believes that, on the one hand, the Stoic spirit of self-discipline emphasizes the importance of silent patience; On the other hand, the teaching of politeness requires that the Japanese should not show their sorrow and pain at the expense of others' happiness and tranquility. For the Japanese, laughter is often used to hide emotions in adversity to restore calm, and it is also a counterweight to sadness and anger [7].

The use of laughter to hide negative emotions is just like the use of rouge to create a vibrant face to hide the haggard heart behind it. The simple self-denial and pursuit of peace of mind of Bushido may be inextrally related to the Japanese national character of suppressing excessive emotional expression, which reflects the unique body view of The Japanese people. Unlike Westerners, who are rich in facial expressions and body language when communicating in public, The Japanese may not see their bodies as containers for emotional expression. Instead, they tend to use their bodies to keep calm and show their perseverance and resilience.

In terms of words and deeds, Hagakure says: "A warrior should pay attention whenever and wherever he is, and should not lag behind others. In particular, it is not possible to speak without thinking, blurt out, to avoid saying: 'I am a coward', 'I ran away', 'I am afraid', 'IT hurts so much', and so on; Not to mention some jokes, jokes, sleep talk, nonsense "; "A samurai should never speak weak words or do stupid things. A small thing, can see through a person's heart "; "It's not polite to yawn in a crowd...... In a word, I should not show my dumb face as if no one was watching." [1] It can be seen that in the view of Yamamoto, the warrior could not show cowardice in front of people, and even could not fully show all self in front of people. The reason for this view may have something to do with the samurai's self-denial described in the previous paragraph.

In addition, Yamamoto paid special attention to the behavior of the warriors before the Lord. "The devotee should not relax all day long. He should always pay attention to his spirit when he is in front of the Lord and when he attends formal occasions. If he thinks he is taking a break and is in a daze, he will always show his feelings in public." [1] In front of the Lord, the warrior should maintain a dignified posture and show his perseverance and respect to the Lord by displaying his calm body.

It can be seen from above that "The consciousness of death" and absolute devotion to the public are regarded as the two main paths that the warriors must follow. In the appearance and words of the warrior, that is, the conventional expression of body language, "consciousness of death" and absolute devotion to public thought kernel have been condensed into it.

\section{SAMURAIS' SEPPUKU -- THE EXTREME EXPRESSION OF BODY LANGUAGE}

Hagakure takes the consciousness of death as the core, and expounds throughout that the samurai must act with determination and not hesitate when deciding to die. Compared with the doctrine of tao, which takes Confucianism as an important guiding ideology, Yamamoto especially emphasizes to die decisively and to include the consciousness of death in the will to live. Therefore, it is of great significance to examine the unique mode of suicide of Japanese samurai -- Seppuku from the perspective of body. 
Seppuku is the exclusive right of the Japanese samurai. In the eyes of outsiders, it may be cruel and bloody seppuku, but it is the most powerful and brilliant death method in the heart of the Japanese samurai. Before the Edo Period, a convicted samurai was not allowed to commit seppuku. Seppuku is an act of self-determination that preserves dignity and honor for the victim of suicide. It is a way for a noble and innocent warrior or a defeated warrior to end his life. [2]

Some scholars have made a careful study of the causes, motives and procedures of the Japanese samurai's seppuku. In terms of origin and origin, seppuku may have been made to imitate the faithful and good scholars in China to prove their innocence. It is also deeply related to ancient divination of internal organs [8]. According to Nitobe Inaz, the abdominal incision was deliberately chosen because ancient anatomy believed that the abdomen was the home of the soul and emotions. Whether it's Moses' "Joseph's heart was burned for his brother," or David's prayer to God not to forget his bowels, or the intestinal pangs and bowel pains experienced by Isaiah, Jeremiah, and other ancient spirituals, all testify to the popular Japanese belief that the soul lives in the belly. Belly cutting means: "I will open the house of the soul and show you what it looks like inside. Please judge for yourself whether it is clear or cloudy." [7]In addition, some scholars also believe that when a warrior cuts himself, his intestines are exposed like a snake, and the snake is believed to be a symbol of the connection between the two worlds, and the soul residing in the belly eventually reaches the other world through the snake's intestines [8].

Nitobe Inaz pointed out that seppuku is not simply a method of suicide, but also a law and a ritual. Invented in the Middle Ages, it was a way for warriors to atone for SINS, thank, insult, redeem friends or show loyalty. As a legal punishment, executed with solemn ceremony, it was a perfect form of self-destruction. Nitobe Inaz then cites Mitford's "Old Japan Stories" to describe the process of seppuku. "Concentrating for the last time, he drove the knife deep into his left abdomen, drew it slowly to his right, then back again, and pulled it up slightly. His facial muscles remained motionless during the agonizing process, which seemed like madness. Then he pulled out his cutlass and bent forward, extending his neck. A look of pain passed over his face, but he made no sound [7]."

This detailed description seems to suggest that the samurai's seppuku was actually a very complete physical manifestation of extreme conditions. The painful cross crossing, the motionless body during suffering, the calm and steady facial expression, and the body falling forward after the "mistake" are all examples of the Japanese samurai's endurance and noble and flawless spirit in the form of physical suffering.

As a matter of fact, samurai is simple and self-denying, which is not a way to express the emptiness and purity of the soul with the calm and simple body. Hereditary warrior education actually starts with the young youth, both physical and tactical skill training, also including the soul and spirit of education, with the ancient Greek citizens military general, perfusion is "life" or "full" concept, the "whole person", body and spirit - to implement in the individual's own personality, and to see it as a samurai identity corresponding obligations. "The whole person" -- body and spirit, even form and language, also believe that the spirit is completed in the construction and observance of the body, the beauty of appearance, the health of the body, the morality of the soul, and the skill, identity and reputation of the warrior are all integrated.

This idea of "whole person" in bushido is quite different from the tradition of western ancient Greek philosophy. In the view of the ancient Greek philosophers, "The power of dualism is not to see the world in its totality, but always to see both sides of the whole world, the whole life. So the Greek philosophers explore the dichotomy, on one side there is absolute being, which is of perfect value; On the other side is absolute nothingness, a false pretence. [9]" This dichotomy puts the body and soul in a position of conflict. The body is ephemeral and perishable, while the soul is immortal and indestructible. If the soul wants to be less harassed by the body, it should learn to refrain from body desires.

However, Benedict, points out that in the chrysanthemum and the sword, in the Japanese point of view, a person's will and behavior can be reached between the "no obstacle, fine hair noted except", it's like the current release directly from the positive to negative, what he did was completely copy the picture from his heart transplant for the person, he can "do".[10] From the perspective of the philosophy of action, Hagakure always values the subject of self. There is no separation between action and the thought of the actor -the subject of action. However, death is often particularly emphasized as the final destination of action.

Under the framework of the philosophy of action in Hagakure, "crazy death" is the ultimate way to make action and thought, body and soul inseparable. The revenge story of Nagasaki ronin and Akho ronin is often compared, that Nagasaki ronin noise without thinking, immediately revenge is the highest, and akho ronin in quanyue temple did not cut belly, it is a regrettable mistake.[1] It can be seen that the radical philosophy of action in Hagakure rejects rationality and makes the unity of body and spirit realized by irrationality based on "consciousness of death" and absolute devotion to justice. The act of seppuku is not only the most extreme 
expression of body language, but also a symbol of Japanese samurai's rationality and irrationality, courage and cowardice of the coexistence of the collective image.

\section{CONCLUSION}

To sum up, this paper takes Hagakure as the center, with the conventional and extreme body view as the entry point, and discusses an alternative bushido thought in the Edo Period represented by Hagakure,. However, although it was rarely read during the Edo Period, It was promoted as a required reading by Japanese nationalists during the war and was considered by some right-wing-elements after the war.

This paper holds that the reason why Hagakure has such enduring appeal lies in its integration of "consciousness of death" and absolute devotion, and it takes irrationality as the key point to realize the unity of action and spirit. In this way, the ideas in Hagakure are not only in line with the Japanese aesthetics and death views, but also can be easily interpreted as the "emperor" by people with ulterior motives. It is easier to realize the unity of action and spirit through irrationality than through self-cultivation and enlightenment. It is more easily accepted by the majority of Japanese people who are deeply affected by "collectivism". Therefore, the radical bushido thought in Hagakure went beyond its original meaning and became one of the bases of militarism and right-wing thoughts under the discourse interpretation during and after the war, which had a profound and lasting influence on Japanese society.

\section{References}

[1]Nagasu Y. (2007) Hagakure, Guangxi Normal University Publishing, Guilin.

[2]Mishima Yukio (2010), the Introduction of Hagakure, Nanjing Literature and Art Publishing, Nanjing.

[3]Albert Craig (2020), Harvard Minimalist History of Japan, Modern Publishing, Beijing.

[4]Zhi W (2007), The Evolution and Theorization of Japanese Bushido, Journal of Northeast Normal University.

[5]Wang, Zhi (2012), A Brief Discussion of Hagakure, Ancient Civilization.

[6]Sun, Huizi (2015), On the reputation view of samurai in Edo period, Master's dissertation, Beijing Foreign Studies University.

[7]Nitobe Inaz (2016), Bushido, Commercial Publishing, Beijing.

[8]Hu, Xinxiang (2009), Analysis of Japanese bushido seppuku, Journal of Chifeng University.
[9]Fang, Dongmei (1987), Original Confucian and Taoist philosophy. Liming Culture Enterprise, publishing, Taibei.

[10] Ruth Benedict (1990), the chrysanthemum and the sword, Commercial Publishing Beijing. 